\title{
118 \\ Conservation significance of privately managed coffee forests of Kodagu, Wetstern Ghats
}

\author{
B N Sathish and C G Kushalappa \\ University of Agricultural Sciences, College of Forestry, Ponnampet, Kodagu, Karnataka India.
}

The main approach for habitat conservation in the past has been the establishment of protected areas. This however, cannot ensure the protection of all the earths' biodiversity. Without tackling the influences leading to environmentally destructive activities, parks don't necessarily attend to the reasons behind the need for protected habitat. They are also highly dependent on the state of surrounding land use. The amount of land in the world currently with protected areas is estimated at five per cent of the earths land surface with remainder being shaped by human managed habitats. Hope for biodiversity lies in the fact that not all agricultural lands are biological deserts, and some agro-systems especially traditional structurally diverse systems can support high levels of biodiversity. Coffee based agroforestry system is one such sub-system and is prevalent in many agrarian regions of the world and also in India. Kodagu, the second smallest district in Karnataka is in the central part of Western Ghats. The district has 73 per cent of its landscape under tree cover and is one of the densest forested districts in India. The diversity of forested ccosystems and associated biodiversity has resulted in Kodagu being identified as micro hotspot of biodiversity. Privately owned and managed coffee plantations are also well wooded and constitute 29 per cent of the landscape and Kodagu produces one third of India's coffec. The present paper tries to throw light on the structure, diversity and conservation significance of coffee based agroforestry systems of Kodagu, a privately managed coffee forests.

\section{9}

\section{Phytosociology of woody vegetation on the eastern slopes of Nilgiris}

\author{
R T Agasimani and K Kumaran \\ Forest College and Research Institute, Mettupalayam (Tamil Nadu), India
}

For proper assessment of biodiversity, its rate of extinction and driving forces leading to extinction, information on the vegetation type, floristic composition and their habitats, human interventions and ultimately impact on landscape changes vis-à-vis biological richness characteristics are required. Nilgiris, the blue mountains of the Southern India, is one of the magnificent and oldest mountain ranges in the world, lying at the junction of Eastern and Western Ghats of the Indian peninsula. Basically, Nilgiris is a hilly area forming part of the environmentally fragile Western Ghats with extremely rich, abundant and wide array of flora and fauna. Botanically, as well as zoologically and ethnologically, the Nilgiris forms a distinct ecological realm of its own and possesses enigmatic affinities to Himalayan flora and fauna. An attempt has been made in this study to analyse the vegetation of eastern slopes of Nilgiris forming part of the famous NBR for its floristic composition and phytosociological aspects during the year $2002-03$.

Results revealed that the vegetation of the entire study area was composed of 166 species distributed among 51 taxonomic families. Among the different vegetation types under study semi-evergreen vegetation was found to be the richest in species composition (117 species), followed by riverine vegetation ( 89 species) and least species richness was registered in deciduous vegetation ( 85 species). Phytosociological studies revealed that Dendrocalamus-Anogeissus-Naringi in deciduous vegetation, Karadisale-Nothopegia-Pamburus in riverine vegetation and Olea-Ligustrum-Anogeissus in case of semi-evergreen vegetation were the dominant plant communities. Semi-evergreen vegetation was found to be dense with nearly 540 individuals per ha and dominant with BA of $41.85 \mathrm{~m}^{2} \mathrm{ha}^{-1}$ followed by riverine vegetation ( 520 individuals per ha and $25.07 \mathrm{~m}^{2} \mathrm{ha}^{-1}$ ) and deciduous vegetation ( 317 individuals per ha and $\left.19.17 \mathrm{~m}^{2} \mathrm{ha}^{-1}\right)$. Among the vegetation types under study contiguous distribution was recorded for majority of species followed by random pattern of distribution. None of the species showed regular distribution pattern. Thus, it can be concluded that all the vegetation types under investigation registered comparatively rich floristic composition. This valuable resource needs to be protected and managed sustainably.

Proceedings of the International Forestry and Environment Symposium 2006 of the Department of Forestry and Environmental Science. University of Sri Jayewardenepura, Sri Lanka 